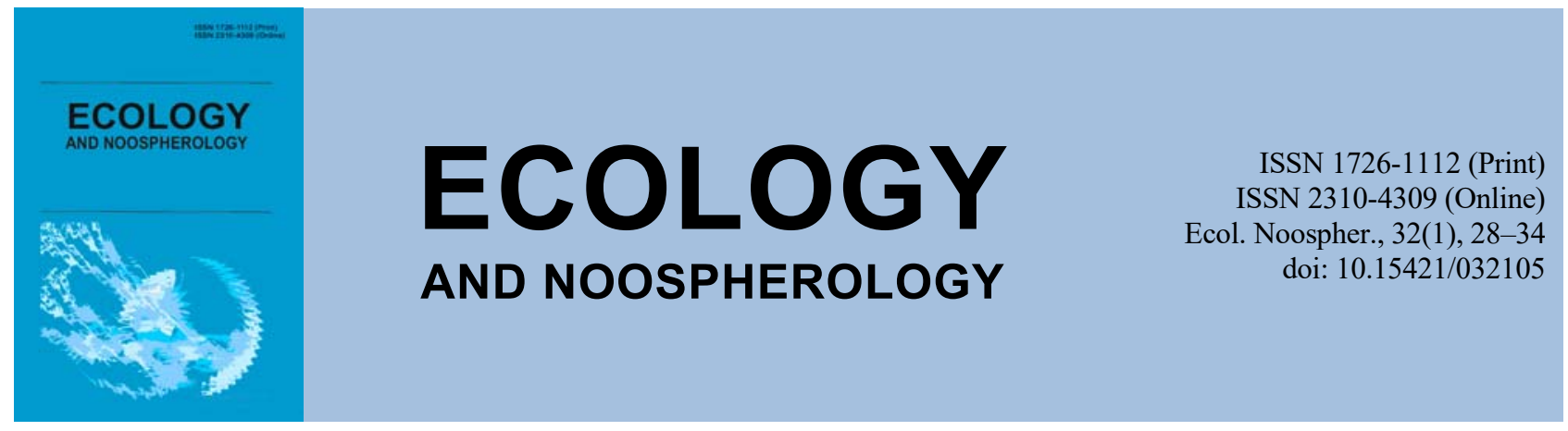

\title{
Influence of forest vegetation on color, reflectivity and humus content in soils of northern variant ravines of the steppe zone of Ukraine
}

\author{
V. A. Gorban, M. S. Yakuba, A. O. Huslystyi \\ Oles Honchar Dnipro National University, Dnipro, Ukraine
}

Article info

Received 15.04.2021

Received in revised form

19.04.2021

Accepted 14.05.2021

Oles Honchar Dnipro

National University,

Gagarin Ave., 72, Dnipro,

49010, Ukraine.

Tel.: +38-050-362-45-90

E-mail:vad01@ua.fm
Gorban, V. A., Yakuba, M. S., Huslystyi, A. O. (2021). Influence of forest vegetation on color, reflectivity and humus content in soils of northern variant ravines of the steppe zone of Ukraine. Ecology and Noospherology, 32(1), 28-34. doi:10.15421/032105

Unique natural forests grow in the conditions of ravines of the steppe zone of Ukraine. Soil scientists have been researching the soils of ravines for more than 60 years. Despite long-term research, aspects of the genesis of specific ravine soils, which are reflected in their optical properties, are still virtually unexplored. Based on this, the aim of our work is to establish the characteristics of the influence of forest vegetation on color and reflectivity, as well as the closely related content of humus in the soils of the northern variant ravines of the steppe zone of Ukraine. Soil samples were taken from each genetic horizon of sections laid in the Glybokyy ravine (near the village of Andriivka, Novomoskovsk district, Dnipropetrovsk region). Soil color indices were determined by scanning soil samples followed by image analysis. The reflectivity of soils was investigated using a monochromator. The humus content in soils was determined by the standard method of wet oxidation of organic matter according to I. V. Tyurin. As a result of the performed researches it is established that the upper horizons of the soils of the Glybokyy ravine differ in the reduced values of the indicators of the HSB, RGB and Lab systems, with depth their values increase. The upper horizons of the ravine soils are characterized by reduced values of brightness coefficients at wavelengths of 480,650 and $750 \mathrm{~nm}$, as well as the integrated brightness coefficient, with depth there is a gradual increase in their values. The color indicators of the RGB and Lab systems are the most successful for diagnosing and predicting the humus content in the soils of the ravine. Forest chernozems and forest-meadow soil of the ravine, which were formed under natural forest vegetation, are characterized by reduced values of color indicators of HSB, RGB and Lab systems, reduced values of brightness coefficients and increased humus content compared to chernozems, the genesis of which is related.

Keywords: chernozem; forest chernozem; forest-meadow soil; color indicators; brightness factor; humus content

\section{Вплив лісової рослинності на колір, відбивну здатність та вміст гумусу в грунтах байраків північного варіанта степової зони України}

\author{
В. А. Горбань, М. С. Якуба, А. О. Гуслистий
}

Дніпровський національний університет імені Олеся Гончара, Дніпро, Україна

Байраки є унікальними природними лісами степової зони України. Грунти байраків уже понад 60 років досліджують грунтознавці Комплексної експедиції з дослідження лісів степової зони Дніпровського національного університету імені Олеся Гончара. Незважаючи на тривалі дослідження, досі залишаються практично невивченими аспекти генезису специфічних байрачних грунтів, які відображаються на їх оптичних властивостях. Виходячи з цього метою нашої роботи $\epsilon$ встановлення особливостей впливу лісової рослинності на колір та відбивну здатність, а також тісно пов'язаний $з$ ними вміст гумусу в грунтах байраків північного варіанта степової зони України. Дослідження виконувалися на прикладі байраку Глибокого. Кольорові показники грунту визначали за допомогою сканування грунтових зразків із подальшим аналізом зображення. Відбивну здатність грунтів досліджували за допомогою монохроматора. Уміст гумусу в грунтах визначали за стандартною методикою мокрого окислення органічної речовини за I. В. Тюріним. В результаті виконаних досліджень 
установлено, що верхні горизонти грунтів байраку Глибокого відрізняються зменшеними значеннями показників систем HSB, RGB та Lab, з глибиною спостерігається зростання їх величин. Верхні горизонти грунтів байраку відрізняються зменшеними величинами коефіцієнтів яскравості при довжинах хвилі 480, 650 та 750 нм, а також інтегрального коефіцієнта яскравості, з глибиною спостерігається поступове зростання їх величин. Кольорові показники систем RGB та Lab $\epsilon$ найбільш вдалими для діагностики та прогнозування вмісту гумусу в грунтах байраку. Чорноземи лісові та лісово-лучний грунт байраку, які сформувалися під природною лісовою рослинністю, характеризуються зменшеними величинами кольорових показників систем HSB, RGB та Lab, зменшеними величинами коефіцієнтів яскравості та збільшеним умістом гумусу порівняно з чорноземами звичайними, генезис яких пов'язаний зі степовою рослинністю.

Ключові слова: чорнозем звичайний; чорнозем лісовий; лісово-лучний грунт; кольорові показники; коефіцієнт яскравості; уміст гумусу

\section{Вступ}

Як відомо, зростання лісової рослинності на чорноземах в умовах степу призводить до покращення їх стану та властивостей (Aderikhin et al., 1983; Belova, 1997; Belova, Travleyev, 1999, 2008; Hrytsan, 2000; Travleyev, Belova, 2008). При цьому найбільш виражений сприятливий вплив лісової рослинності на грунти проявляється в байрачних біогеоценозах (Travleyev et al., 2005; Belova et al., 2010), в яких формуються специфічні чорноземи лісові (Travleyev, 1972; Belgard, Travleyev, 1980), що характеризуються гарним структурним станом, збільшеним умістом гумусу, максимальним насиченням грунтово-поглинального комплексу двовалентними катіонами (переважно кальцієм та частково магнієм), значним зниженням лінії скипання, сприятливими фізичними та хімічними властивостями (Travleyev et al., 2007; Belova, Travleyev, 1999, 2008). Разом 3 тим на сьогодні ще залишаються нерозкритими деякі особливості генезису грунтів байраків, зокрема ті, що пов'язані $з$ їх такими оптичними властивостями, як колір та відбивна здатність. Актуальність дослідження цих властивостей зумовлена також їх значною залежністю від умісту в грунтах органічної речовини.

Метою нашої роботи є дослідження кольору, відбивної здатності та вмісту гумусу в грунтах байраків північного варіанта степової зони України, а також встановлення взаємозв’язків між цими показниками.

\section{Матеріали та методи досліджень}

Грунтові зразки відбирали 3 кожного генетичного горизонту розрізів, закладених у байраку Глибокому (поблизу с. Андріївки Новомосковського р-ну Дніпропетровської обл.).

Детальний опис пробних площ та морфологічну характеристику грунтових профілів наведено в роботах Н. А. Білової, А. П. Травлєєва (Belova, Travleyev, 1999) та В. М. Яковенка (Yakovenko, 2014). Нижче наводимо стислу характеристику досліджуваних об'єктів, використовуючи зазначені роботи.

Пробна площа 1. Розміщена на степовій цілині, розташованій на північній експозиції байраку. Площа має нахил $8^{\circ}$ північної експозиції. У трав'янистому покриві присутні Poa angustifolia L., Elytrigia repens (L.) Nevski, Achillea millefolium L., Salvia nemorosa L., Artemisia absinthium L., Euphorbia vigrata Waldst. et Kit., Galium aparine L., Viola odorata L., Lathyrus tuberosus L., Convolvus arvensis L. Грунт - чорнозем звичайний.

Пробна площа 2. Розташована на середній частині схилу північної експозиції байраку. Площа має нахил $15^{\circ}$ північної експозиції. У деревному ярусі присутні Tilia cordata Mill., Fraxinus excelsior L., Acer platanoides L., Acer campestre L., Ulmus minor Mill. Трав'янистий покрив утворений Glechoma hederacea L., Stellaria holostea L., Chelidonium majus L., Poa nemoralis L., Galium aparine L., Viola odorata L. Грунт - чорнозем лісовий.

Пробна площа 3. Розташована на рівній ділянці тальвегу байраку. У деревному ярусі присутні Fraxinus exelsior L., Acer campestre L., Ulmus minor Mill., Acer platanoides L., Quercus robur L., Tilia cordata Mill. Трав'янистий покрив утворений Stellaria holostea L., Chelidonium majus L., Galium aparine L., Anthriscus sylvestris (L.) Hoffm., Aegopodium podagraria L., Geum urbanum L., Asarum europaeum L., Urtica dioica L., Alliaria petiolata (M. Bied.) Cavara et Grande). Грунт - лісоволучний.

Пробна площа 4. Розташована на середній частині південної експозиції байраку. Площа має нахил $14^{\circ}$ південної експозиції. У деревному ярусі присутні Fraxinus exelsior L., Acer campestre L., Ulmus minor Mill., Tilia cordata Mill., Acer platanoides L. Трав'янистий покрив утворюють Glechoma hederacea L., Viola odorata L., Chelidonium majus L., Galium aparine L., Anthriscus sylvestris (L.) Hoffm., Geum urbanum L., Asarum europaeum L., Trifolium medium L., Aristolochia clematitis L., Potentilla argentea L. Грунт - чорнозем лісовий.

Пробна площа 5. Розташована на степовій цілині, розміщеній на південній експозиції байраку. Площа має нахил $3^{\circ}$ південної експозиції. Трав'янистий покрив утворюють Festuca valesiaca Goud. s.l., Poa angustifolia L., Elytrigia repens (L.) Nevski, Poa nemoralis L., Lathyrus tuberosus L., Achillea millefolium L., Euphorbia vigrata Waldst. et Kit., Thymus marschallianus Willd., Linum hirsutum L., Agrimonia eupatoria L., Medicago romanica Prod., Melica transsilvanica Schur, Salvia nemorosa L. Грунт - чорнозем звичайний.

Визначення кольору грунтів виконували за допомогою сканера (Gorban et al., 2019). Для сканування використовували грунтові зразки, які попередньо зволожували до пастоподібного стану, перемішували, розміщали у спеціальні округлі форми розміром $25 \times 25$ мм та висушували на склі до повітряно-сухого стану. Для подальшого аналізу отриманого зображення з роздільною здатністю 300 пікселей використовували програму Adobe Photoshop, в якому інструмент «піпетка» $(5 \times 5$ пікселей $)$ дозволяє отримувати ряд характеристик кольору об'єкта в кольорових моделях HSB, RGB, CIE L*a*b* та CMYK.

Визначення відбивної здатності виконували за допомогою монохроматора у діапазоні довжин хвиль 400 750 нм шляхом вимірювання спектральних коефіцієнтів яскравості R (Orlov et al., 2001), які виражають відсоткове відношення яскравості об'єкта, що досліджується, до яскравості абсолютно білої поверхні (еталона). Джерелом випромінювання слугувала галогенова лампа. Для дослідження брали фракцію грунту 0,5-1 мм (одна 3 найчисленніших для досліджуваного типу грунту), яку поміщали в кювету 3 кварцу розміром $35 \times 17 \times 5$ мм. Як еталон використовували оксид магнію. Вимірювання відбивної здатності проводили 3 кроком 5 нм, 3 усередненням за трьома значеннями у точці для кожного значення довжини хвилі. Отримані величини відбивної здатності за певних довжин хвиль у подальшому використовували для побудови графіка, який слугував для розрахунків величини R. Застосування такого способу вимірювання дозволяє отримувати 70 значень відбивної здатності для грунтового зразка, що підвищує точність отриманих даних, на відміну від інших способів, де використовуються визначення на окремих довжинах хвиль 400, 550, 670 та 800 нм (Gorban et al., 2019). 
Визначення вмісту органічного вуглецю 3 подальшим розрахунком гумусу виконували за ДСТУ 4289:2004.

\section{Результати досліджень}

\section{Кольорові показники грунтів байраку}

Аналіз кольорових показників чорнозему звичайного пробної площі 1 виявив, що за показниками системи HSB верхні горизонти $\mathrm{Hdk}$, $\mathrm{Hk}$ та $\mathrm{Hpk}$ практично не відрізняються (табл. 1). Зі збільшенням глибини спостерігається зростання величин показників $\mathrm{H}, \mathrm{S}$ та В, при цьому максимальні величини показників $\mathrm{H}$ та $\mathrm{S}$ виявлено в горизонті Phk ( $37^{\circ}$ та $29 \%$ відповідно), а показника В - у горизонті $\mathrm{Pk}(62 \%)$. Мінімальні величини показників R, G та В виявлено в горизонті $\mathrm{Hdk}(95,85$ та 75 відповідно), а максимальні - у горизонті Pk (157, 140 та 114 відповідно). За величинами показників L, a та b горизонти $\mathrm{Hdk}$ та $\mathrm{Hk}$ характеризуються їх мінімальними значеннями і практично не відрізняються між собою. 3 глибиною спостерігається збільшення величини зазначених показників, при цьому горизонти $\mathrm{Phk}$ та $\mathrm{Pk}$ не відрізняються між собою за величинами показників a та b (6 та 18 відповідно). Горизонти Hdk та Hk відрізняються збільшеними величинами показників $\mathrm{C}, \mathrm{M}, \mathrm{Y}$ та $\mathrm{K}$ i практично не відрізняються за цими показниками між собою. 3 глибиною спостерігається зменшення величин цих показників.

Дослідженнями чорнозему лісового пробної площі 2 встановлено, що мінімальні величини показників системи HSB виявлено в горизонтах H1el та H2el, 3 глибиною спостерігається їх зростання до максимальних значень у горизонті Philk. Мінімальні значення показників R, G та B характерні для горизонту H2el (92, 78 та 67 відповідно), 3 глибиною спостерігається зростання їх значень. За величинами показників системи Lab горизонти H1el та $\mathrm{H} 2 \mathrm{el}$ відрізняються мінімальними величинами і практично не відрізняються між собою, 3 глибиною виявлено зростання їх величин. Максимальні величини показників C, M та K спостерігаються в горизонтах H1el та H2el, 3 глибиною їх величини зменшуються (табл. 1). Горизонт H1el відрізняється мінімальним значенням показника Y (66), а 3 глибиною спостерігається зростання його величини до максимальної в горизонті Pilk (78).

Аналіз показників кольору лісово-лучного грунту пробної площі 3 виявив, що мінімальні величини показників $\mathrm{H}$ та S притаманні горизонту $\mathrm{H} 3 \mathrm{el}\left(16^{\circ}\right.$ та $18 \%$ відповідно), показника В - горизонту Hpil (31 \%). Максимальна величина показника Н виявлена в горизонті Hil $\left(28^{\circ}\right)$, показників S та В - у горизонті H1el (24 та $36 \%$ відповідно). Максимальні величини показників системи RGB характерні для горизонту H1el (93, 80 та 71 відповідно), з глибиною спостерігається їх зменшення. Максимальні показники системи Lab також виявлені в горизонті H1el (35, 7 та 9 відповідно), 3 глибиною спостерігається зменшення їх показників (табл. 1). Горизонти H1el та H2el характеризуються зменшеними величинами показників $\mathrm{C}$ та $\mathrm{K}$, збільшеними величинами показника Y. За значеннями показника М горизонти практично не відрізняються між собою.

У результаті дослідження кольорових показників чорнозему лісового пробної площі 4 виявлено, що горизонт H1el відрізняється збільшеними величинами показників $\mathrm{H}$ та S (28 $8^{\circ}$ та 23 \% відповідно) порівняно 3 іншими верхніми горизонтами (табл. 1). Максимальні значення величин цих показників виявлено в нижніх горизонтах. Верхні горизонти відрізняються меншими величинами показника В порівняно 3 нижніми горизонтами, при цьому його мінімальне значення (31\%) виявлено в горизонті Hil. Горизонт Hil відрізняється мінімальними значеннями показників системи RGB. Разом 3 цим верхні горизонти відрізняються меншими величинами показників R, G та B порівняно 3 нижніми горизонтами. Горизонт Hil характеризується мінімальною величиною показника L. У цілому верхні горизонти відрізняються меншими величинами показників системи $\mathrm{Lab}$ порівняно з нижніми горизонтами. Верхні горизонти досліджуваного грунту характеризуються більшими величинами показників С, М та К порівняно $з$ нижніми горизонтами. Зменшені величини показника $\mathrm{Y}$ виявлено у верхніх горизонтах, з глибиною спостерігається зростання його величин.

Дослідженнями кольорових показників чорнозему звичайного пробної площі встановлено, що горизонти $\mathrm{Hdk}$ та Hpk характеризуються меншими величинами показників системи HSB порівняно з горизонтами Phk та Pk (табл. 1). Мінімальні значення показників R, G та В виявлено в горизонті Hpk (94, 84 та 74 відповідно), $з$ глибиною спостерігається зростання їх величин. Горизонт Нpk також відрізняється мінімальними значеннями показників системи Lab, з глибиною спостерігається зростання їх величин. Горизонт Hpk характеризується максимальними значеннями показників С, M, Y та $\mathrm{K}(46,52,67$ та 33 відповідно), з глибиною спостерігається зменшення їх величин.

\section{Відбивна здатність трунтів байраку}

У результаті дослідження чорнозему звичайного пробної площі 1 встановлено, що верхній горизонт $\mathrm{Hdk}$ відрізняється найбільшою довжиною хвилі при максимальному відбитті (650 нм), найменша довжина хвилі максимального відбиття характерна для горизонту $\mathrm{Pk}$ (табл. 2). Найменші величини коефіцієнтів яскравості при довжинах хвиль 480 та 650 нм пов'язані з горизонтом $\mathrm{Hk}$ (8,61 та 10,90 відповідно), з глибиною спостерігається зростання їх значень. Горизонт $\mathrm{Hdk}$ відрізняється найменшими значеннями коефіцієнта яскравості при довжині хвилі 750 нм та інтегрального коефіцієнта яскравості $(15,43$ та 10,01 відповідно), 3 глибиною спостерігається зростання їх величин. У цілому за величинами коефіцієнтів яскравості весь шар грунту можна умовно поділити на два шари: до першого відносяться горизонти $\mathrm{Hdk}$, Hk та Hpk, які характеризуються зменшеними значеннями коефіцієнтів яскравості; до другого відносяться горизонти Phk та Pk, яким властиві збільшені величини коефіцієнтів яскравості.

При аналізі чорнозему лісового пробної площі 2 встановлено, що горизонт $\mathrm{Hlel}$ відрізняється мінімальною величиною довжини хвилі максимального відбиття (605 нм), найбільша величина довжини хвилі максимального відбиття виявлена в горизонті H3el (670 нм). Мінімальна величина коефіцієнта яскравості при довжині хвилі 480 нм пов'язана 3 горизонтом H1el $(6,18), \quad 3$ глибиною спостерігається зростання його значень (табл. 2). У цілому за профілем спостерігається поступове зростання величин коефіцієнтів яскравості і лише горизонт Pilk відрізняється різким збільшенням їх величин.

Дослідження лісово-лучного грунту пробної площі 3 виявили, що горизонт Phil відрізняється найменшою довжиною хвилі максимального відбиття (605 нм), найбільша довжина хвилі максимального відбиття характерна для горизонту Hpil (685 нм). Горизонту H1el властиві найменші значення коефіцієнта яскравості при довжині хвилі 480 нм та інтегрального коефіцієнта яскравості $(7,07$ та 8,34 відповідно), 3 глибиною спостерігається зростання їх значень (табл. 2). Горизонт $\mathrm{H} 2 \mathrm{el}$ відрізняється мінімальними значеннями коефіцієнтів яскравості при довжинах хвиль 650 та 750 нм $(8,51$ та 12,78 відповідно), з глибиною виявлено зростання їх величин.

Аналіз чорнозему лісового пробної площі 4 показав, що найменша величина довжини хвилі максимального відбиття притаманна горизонту Hil (620 нм), а найбільша горизонту H2el (680 нм). Горизонт H1el відрізняється максимальним значенням коефіцієнта яскравості при довжині хвилі 480 нм $(9,01)$, мінімальне значення 


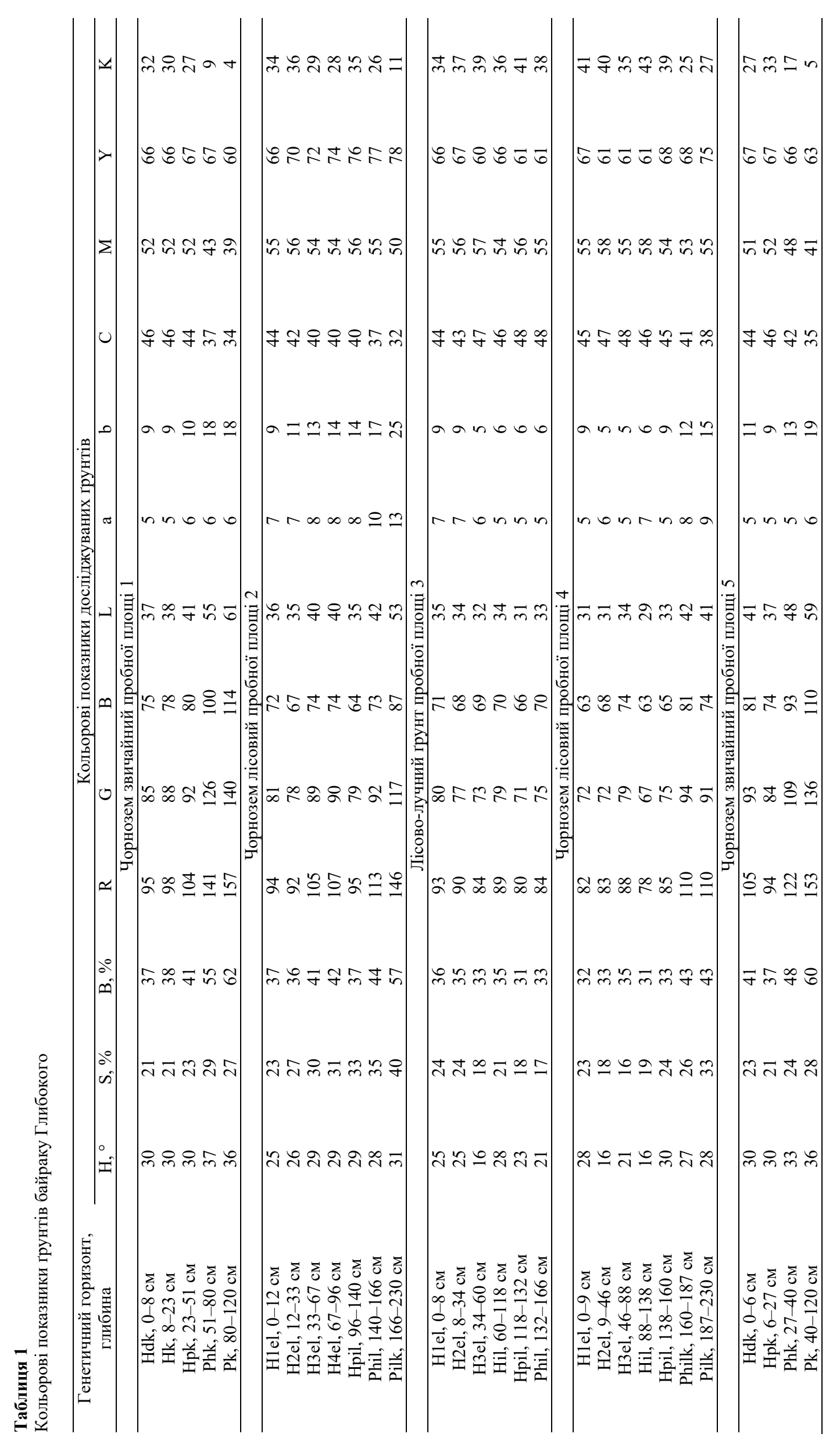




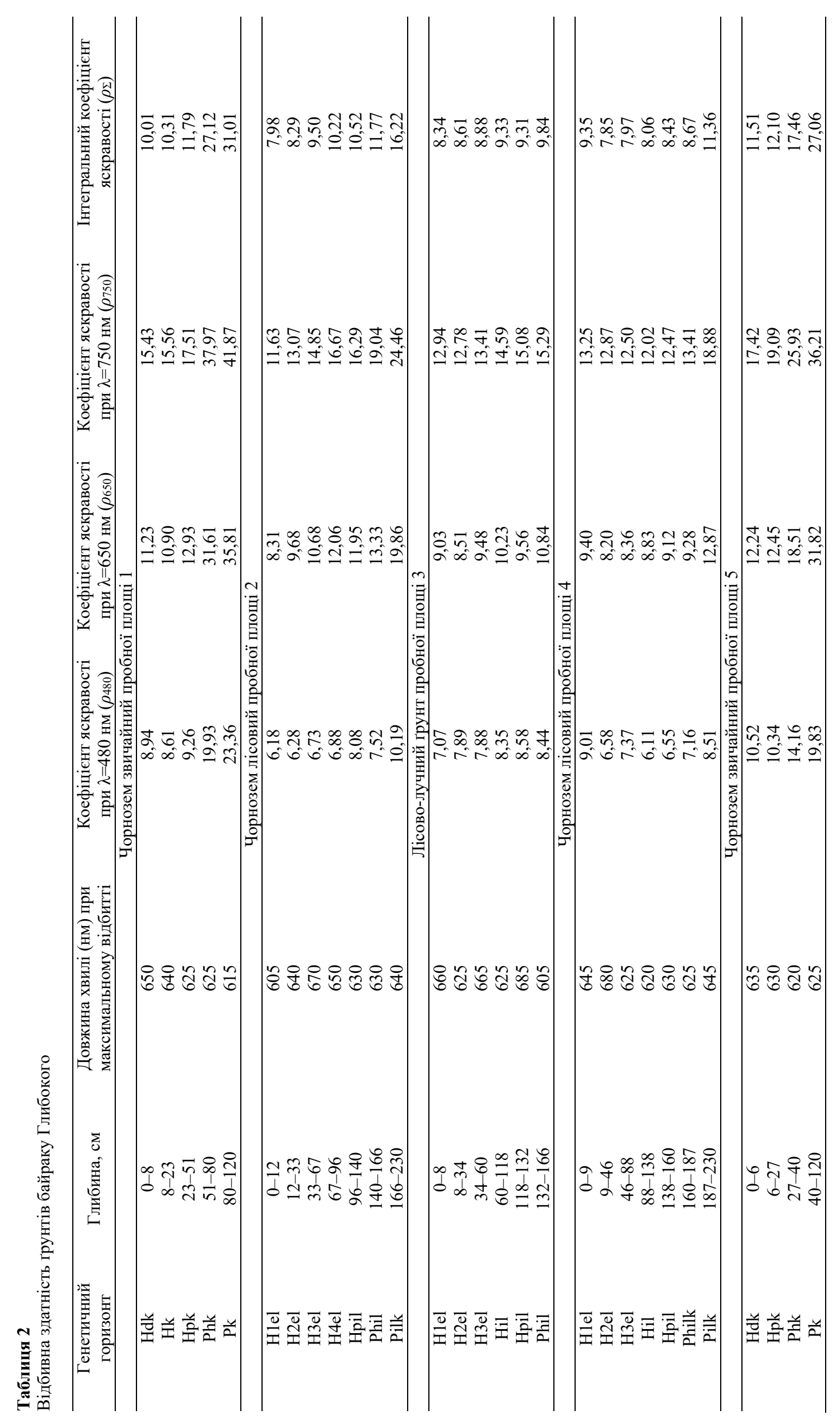


характерне горизонту Hil $(6,11)$. Горизонту H1el також притаманні збільшені величини коефіцієнтів яскравості при довжинах хвиль 650 та 750 нм, а також інтегрального коефіцієнта яскравості (табл. 2). Найменшу величину коефіцієнта яскравості при довжині хвилі 650 нм виявлено в горизонті H1el $(8,20)$. Мінімальна величина коефіцієнта яскравості при довжині хвилі 750 нм характерна для горизонту Hil $(12,02)$. Найменше значення інтегрального коефіцієнта яскравості виявлено в горизонті H2el $(7,85)$. У цілому серед усіх горизонтів досліджуваного грунту горизонт Pilk відрізняється збільшеними величинами коефіцієнтів яскравості при довжинах хвиль 650 та 750 нм, інтегрального коефіцієнта яскравості.

Дослідженнями чорнозему звичайного пробної площі 5 встановлено, що найбільша довжина хвилі максимального відбиття характерна для горизонту $\mathrm{Hdk}$ (635 нм), а найменша - для горизонту Phk (620 нм). Мінімальна величина коефіцієнта яскравості при довжині хвилі 480 нм виявлена в горизонті $\mathrm{Hpk}(10,34), 3$ глибиною спостерігається зростання його величини (табл. 2). Горизонт $\mathrm{Hdk}$ відрізняється мінімальними величинами коефіцієнтів яскравості при довжинах хвиль 650 та 750 нм, інтегрального коефіцієнта яскравості (12,24, 17,42 та 11,51 відповідно), 3 глибиною спостерігається зростання величин цих показників. У цілому досліджений грунт можна поділити на два шари: до першого відносяться горизонти Hdk тa Hpk, які відрізняються зменшеними величинами коефіцієнтів яскравості; до другого належать горизонти $\mathrm{Phk}$ та $\mathrm{Pk}$, яким притаманні збільшені величини коефіцієнтів яскравості.

\section{Уміст гумусу в трунтах байраку}

Аналіз умісту гумусу в чорноземі звичайному пробної площі 1 показав, що його максимальний уміст $(7,37 \%)$ властивий для горизонту Hdk, 3 глибиною спостерігається зменшення вмісту гумусу до 0,09 \% в горизонті $\mathrm{Pk}$ (табл. 3).

Таблиця 3

Уміст гумусу у грунтах байраку Глибокого

\begin{tabular}{|c|c|c|}
\hline $\begin{array}{c}\text { Генетичний } \\
\text { горизонт }\end{array}$ & Глибина, см & Уміст гумусу, \% \\
\hline \multicolumn{3}{|c|}{ Чорнозем звичайний пробної площі 1} \\
\hline Hdk & $0-8$ & 7,37 \\
\hline $\mathrm{Hk}$ & $8-23$ & 4,10 \\
\hline Hpk & $23-51$ & 2,03 \\
\hline Phk & $51-80$ & 0,77 \\
\hline $\mathrm{Pk}$ & $80-120$ & 0,09 \\
\hline \multicolumn{3}{|c|}{ Чорнозем лісовий пробної площі 2} \\
\hline H1el & $0-12$ & 8,25 \\
\hline $\mathrm{H} 2 \mathrm{el}$ & $12-33$ & 5,50 \\
\hline H3el & $33-67$ & 2,36 \\
\hline $\mathrm{H} 4 \mathrm{el}$ & $67-96$ & 1,04 \\
\hline Hpil & $96-140$ & 0,94 \\
\hline Phil & $140-166$ & 0,63 \\
\hline Pilk & $166-230$ & 0,20 \\
\hline \multicolumn{3}{|c|}{ Лісово-лучний грунт пробної площі 3} \\
\hline H1el & $0-8$ & 7,29 \\
\hline $\mathrm{H} 2 \mathrm{el}$ & $8-34$ & 7,77 \\
\hline $\mathrm{H} 3 \mathrm{el}$ & $34-60$ & 5,23 \\
\hline Hil & $60-118$ & 4,22 \\
\hline Hpil & $118-132$ & 4,02 \\
\hline Phil & $132-166$ & 3,91 \\
\hline \multicolumn{3}{|c|}{ Чорнозем лісовий пробної площі 4} \\
\hline H1el & $0-9$ & 9,06 \\
\hline $\mathrm{H} 2 \mathrm{el}$ & $9-46$ & 4,79 \\
\hline $\mathrm{H} 3 \mathrm{el}$ & $46-88$ & 2,56 \\
\hline Hil & $88-138$ & 2,76 \\
\hline Hpil & $138-160$ & 1,24 \\
\hline Philk & $160-187$ & 1,14 \\
\hline Pilk & $187-230$ & 0,23 \\
\hline \multicolumn{3}{|c|}{ Чорнозем звичайний пробної площі 5} \\
\hline Hdk & $0-6$ & 7,03 \\
\hline Hpk & $6-27$ & 3,72 \\
\hline Phk & $27-40$ & 1,71 \\
\hline $\mathrm{Pk}$ & $40-120$ & 0,12 \\
\hline
\end{tabular}

У чорноземі лісовому пробної площі 2 максимальний уміст гумусу $(8,25 \%)$ виявлено в горизонті $\mathrm{Hlel}, 3$ глибиною спостерігається зменшення його вмісту до $0,20 \%$ в горизонті Pilk (табл. 3).

У лісово-лучному грунті пробної площі 3 максимальний уміст гумусу (7,77 \%) характерний для горизонту H2el, з глибиною спостерігається поступове зменшення його вмісту до 3,91 \% в горизонті Phil (табл. 3).

Максимальний уміст гумусу в чорноземі лісовому пробної площі 4 пов'язаний з горизонтом H1el (9,06 \%), з глибиною його вміст зменшується до $0,23 \%$ в горизонті Pilk (табл. 3).

У чорноземі звичайному пробної площі 5 максимальний уміст гумусу виявлено в горизонті $\mathrm{Hdk}(7,03$ \%), 3 глибиною спостерігається зменшення його вмісту до 0,12 \% в горизонті $\mathrm{Pk}$ (табл. 3).

\section{Взасмозв'язок мізс кольором, відбивною здатністю та} вмістом гумусу в трунтах байраку

Для виявлення особливостей взаємозв'язків між досліджуваними показниками грунтів байраку нами було розраховано парні коефіцієнти кореляції між кольоровими показниками та інтегральним коефіцієнтом яскравості, між умістом гумусу та кольоровими показниками, між інтегральним коефіцієнтом яскравості та вмістом гумусу.

Аналіз чорнозему звичайного пробної площі 1 виявив, що найбільш тісний прямий, практично лінійний, зв'язок характерний для інтегрального коефіцієнта яскравості та показників B $(\mathrm{r}=0,99), \mathrm{R}(\mathrm{r}=1,00), \mathrm{G}(\mathrm{r}=1,00), \mathrm{B}(\mathrm{r}=$ $0,99), \mathrm{L}(\mathrm{r}=1,00)$ та $\mathrm{b}(\mathrm{r}=0,99)$. Тісний зворотний зв'язок виявлено між інтегральним показником яскравості та показниками $\mathrm{C}(\mathrm{r}=-0,99), \mathrm{M}(\mathrm{r}=-0,99)$ та $\mathrm{K}(\mathrm{r}=-1,00)$. Менш тісний зворотний зв'язок встановлено між умістом гумусу та кольоровими показниками $\mathrm{S}(\mathrm{r}=-0,82), \mathrm{B}(\mathrm{r}=$ $-0,83), R(r=-0,82), G(r=-0,82), L(r=-0,83), a(r=-0,89)$. Прямий зв'язок виявлено між умістом гумусу та кольоровими показниками $\mathrm{C}(\mathrm{r}=0,83), \mathrm{M}(\mathrm{r}=0,76)$ та $\mathrm{K}$ $(\mathrm{r}=0,84)$. Коефіцієнт кореляції між інтегральним коефіцієнтом яскравості та вмістом гумусу дорівнює - 0,80 .

Дослідження зв'язків між досліджуваними показниками чорнозему лісового пробної площі 2 виявило існування тісного прямого зв'язку між інтегральним коефіцієнтом яскравості та показниками $\mathrm{S}(\mathrm{r}=0,94), \mathrm{B}(\mathrm{r}=$ $0,95), \mathrm{R}(\mathrm{r}=0,95), \mathrm{a}(\mathrm{r}=0,98), \mathrm{b}(\mathrm{r}=1,00)$. Тісний зворотний зв'язок встановлено між інтегральним коефіцієнтом яскравості та показниками $\mathrm{C}(\mathrm{r}=-0,98)$ та $\mathrm{K}(\mathrm{r}=-0,93)$. Також тісний зворотний зв'язок виявлено між умістом гумусу та показниками $\mathrm{H}(\mathrm{r}=-0,91), \mathrm{S}(\mathrm{r}=-0,90), \mathrm{Y}(\mathrm{r}=$ - 0,96). Коефіцієнт кореляції між інтегральним коефіцієнтом яскравості та вмістом гумусу дорівнює - 0,72.

Аналіз зв'язків лісово-лучного грунту пробної площі 3 показав існування тісного зворотного зв'язку між інтегральним коефіцієнтом яскравості та показниками $\mathrm{S}$ $(\mathrm{r}=-0,80)$ та $\mathrm{a}(\mathrm{r}=-0,92)$. Тісний прямий зв'язок виявлено між інтегральним коефіцієнтом яскравості та показником $\mathrm{C}(\mathrm{r}=0,81)$. Також тісний прямий зв'язок характерний між умістом гумусу та показниками $\mathrm{S}(\mathrm{r}=0,87), \mathrm{R}(\mathrm{r}=0,75)$, а $(\mathrm{r}=0,99)$ та $\mathrm{b}(\mathrm{r}=0,87)$. Тісний зворотний зв'язок встановлено між умістом гумусу та показником С (r = - 0,93). Коефіцієнт кореляції між інтегральним коефіцієнтом яскравості та вмістом гумусу дорівнює - 0,90.

Дослідженнями чорнозему лісового пробної площі 4 встановлено існування тісного прямого зв'язку між інтегральним коефіцієнтом яскравості та показниками $\mathrm{S}$ $(\mathrm{r}=0,90), \mathrm{b}(\mathrm{r}=0,87)$ та $\mathrm{Y}(\mathrm{r}=0,91)$. Тісний зворотний зв'язок характерний між інтегральним коефіцієнтом яскравості та показником $\mathrm{C}(\mathrm{r}=-0,86)$. Тісних зв'язків між умістом гумусу та кольоровими показниками, а також між інтегральним коефіцієнтом яскравості та вмістом гумусу не виявлено.

Аналіз зв'язків чорнозему звичайного пробної площі 5 виявив існування тісного прямого зв'язку між 
інтегральним коефіцієнтом яскравості та показниками $\mathrm{H}$, $\mathrm{S}, \mathrm{B}, \mathrm{R}, \mathrm{G}, \mathrm{B}, \mathrm{L}$, а та $\mathrm{b}$ ( $\mathrm{r}$ у межах 0,93-0,98). Тісний зворотний зв'язок характерний між інтегральним коефіцієнтом яскравості та показниками $\mathrm{C}, \mathrm{M}, \mathrm{Y}$ та $\mathrm{K}$ ( $\mathrm{r}$ у межах - 0,96- - 0,99). Також тісний зворотний зв'язок властивий між умістом гумусу та кольоровими показниками $\mathrm{H}(\mathrm{r}=-0,87)$, B, R, G, B та L ( $\mathrm{r}=-0,77-$ - 0,78). Тісний прямий зв'язок виявлено між умістом гумусу та показниками $\mathrm{M}$ та $\mathrm{Y}$ ( $\mathrm{r}$ дорівнює 0,79 та 0,80 відповідно). Коефіцієнт кореляції між інтегральним коефіцієнтом яскравості та вмістом гумусу дорівнює - 0,86 .

\section{Обговорення}

У результаті проведених досліджень установлено, що найменші значення показників системи HSB характерні для верхніх горизонтів чорнозему лісового пробної площі 2 та лісово-лучного грунту пробної площі 3 . Найбільші значення зазначених показників пов'язані 3 верхнім горизонтом чорноземів звичайних пробних площ 1 та 5. Найменші показники систем RGB та Lab характерні для верхнього горизонту чорнозему лісового пробної площі 4 , який також характеризується максимальним умістом гумусу серед усіх досліджених грунтів. Лісово-лучний грунт пробної площі 3 характеризується збільшеними значеннями зазначених показників, а максимальними значеннями відрізняється верхній горизонт чорнозему звичайного пробної площі 5 (з мінімальним умістом гумусу). За показниками системи СМYК верхні горизонти досліджених грунтів практично не відрізняються між собою.

Верхній горизонт чорнозему лісового пробної площі 2 характеризується найменшими величинами коефіцієнтів яскравості, а найбільшими - верхній горизонт чорнозему звичайного пробної площі 5 , який відрізняється мінімальним умістом гумусу серед верхніх горизонтів усіх досліджуваних грунтів.

\section{Висновки}

1. Верхні горизонти грунтів байраку Глибокого відрізняються зменшеними значеннями показників систем HSB, RGB та Lab, з глибиною спостерігається зростання їх величин.

2. Верхні горизонти досліджуваних грунтів характеризуються збільшеними значеннями показників системи СМYК, з глибиною спостерігається зменшення їх величин.

3. Найбільш чіткі зміни величин кольорових показників за грунтовим профілем властиві чорноземам звичайним пробних площ 1 та 5 , найменш чіткими змінами відрізняється лісово-лучний грунт пробної площі 3.

4. Верхні горизонти грунтів байраку відрізняються зменшеними величинами коефіцієнтів яскравості при довжинах хвилі 480, 650 та 750 нм, а також інтегрального коефіцієнта яскравості, 3 глибиною спостерігається поступове зростання їх величин.

5. Кольорові показники систем RGB та Lab $є$ найбільш вдалими для діагностики та прогнозування вмісту гумусу в грунтах байраку.

6. Чорноземи лісові та лісово-лучний грунт байраку, які сформувалися під природною лісовою рослинністю, характеризуються зменшеними величинами кольорових показників систем HSB, RGB тa Lab, зменшеними величинами коефіцієнтів яскравості та збільшеним умістом гумусу порівняно з чорноземами звичайними, генезис яких пов'язаний зі степовою рослинністю.

\section{References}

Aderikhin, P. G., Belgard, A. L., Zonn, S. V., Krupenikov, I. A., Travelyev, A. P. (1983). Vliyaniye lesnoy rastitelnosti na chernozemy [Influence of forest vegetation on chernozems]. Russian black earth -100 years after Dokuchaev. Moscow, 117-126 (in Russian).

Belgard, A. L., Travleyev, A. P. (1980). Izucheniye vzaimodeystviya rastitelnosti $\mathrm{s}$ pochvami $\mathrm{v}$ lesnykh biogeotsenozakh stepnoy Ukrainy v svete vozzreniy S. V. Zonna [Study of the interaction of vegetation with soils in forest biogeocenoses of steppe Ukraine in the light of the views of S. V. Zonn]. Questions of biological diagnostics of forest biogeocenoses in the Samaria region. Dnepropetrovsk, DGU, 5-12 (in Russian).

Belova, N. A., Travleyev, A. P. (2008). Evolutsiaia i genesis pochv pod lesnymi fitocenozami $\mathrm{v}$ stepi [Evolution and genesis of soils under forest phytocenoses in the steppe]. Issues of steppe forestry and forest reclamation of lands. Dnipropetrovsk, DNU, 3-10 (in Russian).

Belova, N. A., Travleyev, A. P., Bogovin, A. V., Chernyshenko, V. S. (2010). Evolyutsiya i genezis pochv pod bayrachnymi lesnymi fitotsenozami v stepi [Evolution and genesis of soils under ravine forest phytocenoses in the steppe]. Gruntoznavstvo, 11, 1-2, 16-27 (in Russian).

Belova, N. A. (1997). Ekologiya, mikromorfologiya, antropogenez lesnykh pochv stepnoj zony Ukrainy [Ecology, micromorfology, antropogenesis of forest soils in the Steppe zone of Ukraine]. Dnepropetrovsk University Press, Dnepropetrovsk (in Russian).

Belova, N. A., Travleyev, A. P. (1999). Estestvennye lesa i stepnye pochvy (ecologiia, mikromorfologiia, genesis) [Forest and steppe soils (ecology, micromorphology, genesis)]. Dnipropetrovsk (in Russian).

Gorban, V. A., Khmelenko, O. V., Huslistyj, A. O., Tetiukha, O. G. (2019). Vplyv lisovoi roslynnosti na kolir, vidbyvnu zdatnist ta vmist gumusu $\mathrm{v}$ chornozemakh zvychainykh Influence of forest vegetation on color, reflectivity and humus content in ordinary chernozems]. Issues of steppe forestry and forest reclamation of soils, 48, 25-37 (in Ukrainian).

Hrytsan, Yu. I. (2000). Ekolohichni osnovy peretvoryuyuchoho vplyvu lisovoyi roslynnosti na stepove seredovyshche [Ecological bases of the transformative influence of forest vegetation on the steppe environment]. Dnipropetrovsk (in Ukrainian)

Orlov, D. S., Suchanova, N. I., Rosanova, M. S. (2001). Spektralnaia otrazhatelnaia sposobnost pochv i ikh komponentov [Spectral reflectance of soils and their components]. Moskva, MSU (in Russian).

Travleyev, A. P. (1972). Materialy k nomenklature i klassifikatsii lesnykh pochv podzony nastoyashchikh stepey [Materials to the nomenclature and classification of forest soils of the subzone of these steppes]. DSU, Dnepropetrovsk. Issues of steppe forestry, 3, 16-21 (in Russian).

Travleyev, A. P., Belova, N. A. (2008). Les kak faktor pochvoobrazovaniya [Forest as a factor in soil formation]. Ġruntoznavstvo, 9, 3-4, 6-26 (in Russian).

Travleyev, A. P., Bilova, N. A., Bogovin, A. V., Dubina, A. O. (2005). Bajrachnye lesa byvshej porozhystoj chasti Dnepra sostavnaya chast ekologicheskoj seti yuga Ukrainy [Valley forests of the previous Dnipro river rapids - as component of south Ukraine ecological net]. Ecology and noospherology, 16, 3-4, 75-94 (in Russian).

Travleyev, A. P., Recio Espejo, J. M., Belova, N. A., Kuuznetzov, J. V., Balalajev, A. K., Kuuznetzov, V. J. (2007). Mikromorfologiya lessivazhnykh protsessov v bayrachnykh lesnykh chernozemakh stepnoy zony Ukrainy [Micromorpholodgy of the intersoil processes typical for ravine forests' chernozem of the Ukrainian steppe zone]. Gruntoznavstvo, 8, 1-2, 6-24 (in Russian).

Yakovenko, V. M. (2014). Vplyv delyuvialnykh protsesiv na macro- ta mikromorfologiyu bairachnykh lisovykh gruntiv [The influence of deluvial processes on macro- and micromorphology of ravined forest soil]. Gruntoznavstvo, $15,3-4,74-88$ (in Ukrainian). 